Military Technical College Kobry Elkobbah, Cairo,

Egypt.

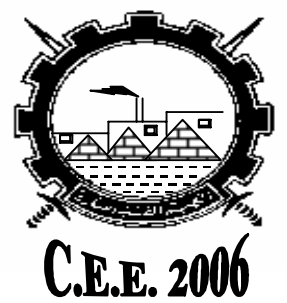

$3^{\text {rd }}$ International Conference

On

Chemical \& Environmental

Engineering

\title{
BIODEGRDATION POTENTIALS OF BACTERIA ISOLATED FROM EGYPTIAN HYDROCARBON POLLUTED SOIL ON POLYAROMATIC HYDROCARBONS AND CRUDE OIL
}

\author{
Farahat L. A*, El-Gendy N. Sh.* and EI-Baz A. F. **
}

\section{ABSTRACT}

Biodegradation of polyaromatic hydrocarbons (PAHs) was performed using hydrocarbon degrading bacteria isolated from Egyptian hydrocarbon polluted soil. Naphthalene (Naph.) was considered as a model of diaromatic ring compounds, while phenanthrene (Phn.) and anthracene (Anth.) were considered as models of tricyclic aromatic hydrocarbons. Eight bacterial strains were isolated from different collected oil polluted soil samples. Only two bacterial isolates; Pseudomonas aeruginosa ALN6 and Brevibacterium casei ALN7 have shown an obvious biodegradation potential of $99.90 \%$ and $99.97 \%$, respectively on $1000 \mathrm{ppm}$ Phn. after 7 days of incubation. Biodegradation potentiality on Phn. was also examined using PAHs mixture (Naph., Phn. and Anth.) in a total concentration of 1000ppm. Brevibacterium casei ALN7 showed nearly the same biodegradation efficiency on Phn. in both sole substrate and PAHs mixture systems $(99.97 \%$ and $98.10 \%$, respectively). However, Pseudomonas aeruginosa ALN6 showed a great difference on Phn. in sole substrate and PAHs systems (99.90\% and $35.38 \%$, respectively). Biodegradation efficiency of both bacterial isolates was also examined on crude oil. They both showed high biodegradation ability of $97 \%$ and $95 \%$ for Brevibacterium casei ALN7 and Pseudomonas aeruginosa ALN6, respectively after four weeks of incubation. However, ALN6 was superior for degrading normal and iso- paraffins while ALN7 was superior for degrading unresolved complex mixture (UCM).

\section{KEY WORDS}

Biodegradation, polyaromatic hydrocarbons (PAHs), crude oil, Pseudomonas aeruginosa, Brevibacterium casei.

\footnotetext{
*Egyptian Petroleum Research Institute.

"faculty of science, Menoufiya University.
} 


\section{INTRODUCTION}

Oil pollution problems have become the focus of increasing regulatory, public and research concern because of its adverse impacts on human health and environment.

The group of chemical compounds known as polycyclic aromatic hydrocarbons (PAHs) represents an important class of compounds that affect the environment. They form a class of organic pollutants ubiquitous in the aquatic ecosystem, showing lipophilic character and resistance to biodegradation [1].

The PAHs contamination may result from either pyrogenic sources (incomplete combustion of organic matter, emission sources and exhausts) or from the release of petroleum into the environment [2]. After entering the environment, PAHs are widely dispersed by atmospheric transport or through stream pathways and eventually accumulated in soil and aquatic sediments [3].

There is a wide range of PAHs, from the simple two-ring compound naphthalene to large multi-ring compounds. Those PAHs with two or three rings are arbitrarily defined as low molecular weight (LMW) species, and those with four or more rings as high molecular weight (HMW) species [4].

The US Environmental Protection Agency (EPA) currently regulates 16 PAHs compounds as priority pollutants in water, and generally considers these compounds as "total PAH" (tPAH) in contaminated sites and has listed them as priority pollutants for remediation [5-6]. The 16 regulated PAH comprise both low and high molecular weight species, and seven of them are designated as known human carcinogens. In addition to their toxicity, PAH as a class are extremely hydrophobic chemicals. Despite their very low solubility in water, PAHs-contaminated materials have been shown to be toxic in a variety of bioassays [7]. The toxicity of naphthalene (Naph.) has been well documented for laboratory animals and human beings [8-9]. Phenanthrene (Phn.) is often used as a model for studies on the metabolism of carcinogenic PAHs $[3,10]$.

Microbiologists have known for a long time that microorganisms can act on most of the PAHs of concern. For this reason, PAH-contaminated soils and sediments are generally considered to be candidates for bioremediation. The genera most frequently mentioned as PAHs degrading bacteria are Pseudomonas, Arthrobacter, Flavobacterium, Acinetobacter, Vibrio, Bacilus, Brevibacterium, Micrococcus and Corynebacterium. The microorganisms (naturally occurring or genetically engineered) can mineralize toxic PAHs into $\mathrm{CO}_{2}$ and $\mathrm{H}_{2} \mathrm{O}$. Many microorganisms evolve catabolic pathways to degrade aromatic compounds. In general, many aromatic substrates are degraded by a limited number of reactions: hydroxylation, oxygenolytic ring cleavage, isomerization and hydrolysis [3,11].

Naph. is considered as the first member of the PAHs groups and a model for the diaromatic ring compounds [3,12-13]. Anthracene (Anth.) and Phn. are tricyclic aromatic hydrocarbons that are found in high concentrations in hydrocarbon contaminated sediments, surface soils and waste sites [14]. They have been used as model compounds to determine factors that affect the bioavailability, biodegradation potential, and rate of microbial degradation of PAHs in the environment [4, 14-16]. 
The aim of this work is to study the biodegradation potential of bacteria isolated from Egyptian hydrocarbon polluted soil on phenanthrene (Phn.) as a model for PAHs compounds in both sole substrate and PAHs mixture systems. Also the efficiency of the selected bacterial isolates on biodegradation of crude oil will be studied.

\section{MATERIALS AND METHODS}

\section{Luria-Bertani broth medium (LB)}

Tryptone $10 \mathrm{~g}$, yeast extract $5 \mathrm{~g}$ and $\mathrm{NaCl} 10 \mathrm{~g}$ were dissolved in one liter distilled water; $\mathrm{pH}$ was adjusted to 7.0 with $10 \% \mathrm{NaOH}$. For maintenance and counting purposes; LB broth medium was solidified with $2 \%$ agar [17].

\section{Basal Salts medium (BSM)}

$\mathrm{Na}_{2} \mathrm{HPO}_{4} 5.57 \mathrm{~g}, \mathrm{KH}_{2} \mathrm{PO}_{4} 2.44 \mathrm{~g}, \mathrm{NH}_{4} \mathrm{Cl} 2.0 \mathrm{~g} \mathrm{MgCl} 2.6 \mathrm{H}_{2} \mathrm{O} 0.2 \mathrm{~g}, \mathrm{FeCl}_{3} .6 \mathrm{H}_{2} \mathrm{O} 0.001 \mathrm{~g}$ and $\mathrm{CaCl}_{2} .2 \mathrm{H}_{2} \mathrm{O} 0.001 \mathrm{~g}$ were dissolved in one liter distilled water, $\mathrm{pH}$ was adjusted to 7.0 with $10 \% \mathrm{NaOH}[18]$.

\section{Belayim mix (BX) crude oil}

BX was used in this study, having the following specifications;

Sulfur content: $2.1 \mathrm{wt} . \%$

API gravity: 27.5

Specific gravity at $60^{\circ} \mathrm{F}: 0.89$

Pour point: $3^{\circ} \mathrm{C}$

Kinematic viscosity at $100^{\circ} \mathrm{F}: 18 \mathrm{cSt}$.

\section{Methods of analysis}

\section{High performance liquid chromatographic analysis (HPLC)}

HPLC model Waters 600E equipped with a dual wavelength UV detector model Waters 2487 (set at 254nm) was used for following up the depletion of PAH using the following system [6];

Column: Supelcosil. LC-PAH, $5 \mu \mathrm{m}$ particles, $15 \mathrm{~cm}$ length and $4.6 \mathrm{~mm}$ ID

Mobile phase: acetonitrile: $\mathrm{H}_{2} \mathrm{O}(60: 40 \mathrm{v} / \mathrm{v})$, HPLC grade

Flow rate: $0-2 \mathrm{~min} ; 0.2 \mathrm{ml} / \mathrm{min}, 2-15 \mathrm{~min} ; 1 \mathrm{ml} / \mathrm{min}$.

Standard curve was established.

PAHs standards were obtained from Supelco.

\section{GC-FID analysis}

GC Instrument model Agilent 6890 equipped with a FID detector was used for following up the degree of biodegradation of crude oil using the following system;

Column: Capillary HP-1 (polymethylsiloxane) $30 \mathrm{~m}$ X 0.35 I. D. (mm) X 0.25 Film $(\mu \mathrm{m})$ Injector: $320^{\circ} \mathrm{C}$

FID programmed; from $100^{\circ} \mathrm{C}$ (oven temperature) to $320^{\circ} \mathrm{C}$ at fixed rate $5^{\circ} \mathrm{C} / \mathrm{min}$.

Carrier gas: nitrogen with flow rate; $2 \mathrm{ml} / \mathrm{min}$

Sample size: $0.5 \mu \mathrm{l}$ 


\section{Collection and preparation of samples used for isolating biodegrading microorganisms (BDM)}

Oily soil samples were collected in triplicate in screw-capped sterile dark glass jars from different locations. The samples were then transferred within 5-6 hours in an ice box to the laboratory, where isolation steps were carried out immediately. Samples used for hydrocarbon assessment; were collected using the same steps as previously mentioned, but were acidified with concentrated $\mathrm{HCl}$ to $\mathrm{pH}$ below 2.0 and preserved in refrigerator at $4^{\circ} \mathrm{C}$ to stop bacterial action until applying them to hydrocarbon extraction and chemical analysis [19-20].

\section{Characterization of polluted soil samples}

Extraction and analysis of total petroleum hydrocarbons (TPH) from oily soil (OS) was carried out as follows; Soil dry mass ( $\mathrm{dm}$ ) and moisture content were determined from the weight loss after heat treatment for $20 \mathrm{~h}$ at $105^{\circ} \mathrm{C}$ [21]. Extraction of dried soil sample in a Soxhlet extractor apparatus using a mixture of $n$-hexane and dichloromethane $(1: 1 \mathrm{v} / \mathrm{v})$ was done [22]. The TPH concentration in the extract was determined gravimetrically [23]. The extracted oil samples were analyzed employing GC/FID. to identify its source and degree of weathering [24].

\section{Enrichment and isolation of BDM}

This was done for enriching, detecting and assessing the size of indigenous BDM in the sediment samples used for isolation according to Duarte et Al., [25] and AbbadAndaloussi et Al., [26], with some modifications. 0.5 gram portion of each sample was mixed with $30 \mathrm{ml}$ of LB medium (in $100 \mathrm{ml}$ conical flasks), Flasks were incubated at $30^{\circ} \mathrm{C}$ for 168 hours on a rotary shaker (200rpm). Serial dilutions were inoculated on LB/agar plates and incubated at $30^{\circ} \mathrm{C}$ for 48 hours. Separate colonies were streaked on LB/agar plates for further purification.

\section{Selection of biodegrading bacterial isolates}

Each of the collected bacterial isolates was incubated separately at $30^{\circ} \mathrm{C}$ in LB broth medium for 24 hours in a shaking incubator (200rpm). Cells were pelleted by centrifugation at $5000 \mathrm{rpm}$ for $15 \mathrm{~min}$, washed three times with BSM and then inoculated separately into BSM that contained phenanthrene dissolved in ethylether in a final concentration of $1000 \mathrm{ppm}$ as a sole source of carbon. The inocula were adjusted so that the absorbance $\left(A_{600}\right)$ at zero time was $\left(I_{0} 0.1\right)$. The cultures were incubated at $30^{\circ} \mathrm{C}$ for 7 days, in a rotary shaking incubator (200rpm). The growth was monitored by measuring optical density (I) at $600 \mathrm{~nm}$, using UV/Nis spectrophotometer (UNICAM, model 8625); non inoculated BSM was used as blank. $\mathrm{pH}$ of the cultures was monitored at the prescribed time with $\mathrm{pH}$-meter (HANNA, model 213). Culture broth was acidified to $\mathrm{pH} 2$ using $1 \mathrm{mM} \mathrm{HCl}$, extracted with equal volume of ethylacetate, and then it was subjected to HPLC analysis. 


\section{Identification of the biodegrading bacterial isolates}

Identification of the selected bacterial isolates; ALN6 and ALN7 was conducted by using Biolog Microlog3 4.20 program.

\section{Biodegradation potentialities of the bacterial isolates}

Bacterial isolates which showed growth and biodegradation potentials on Phn. were inoculated separately into BSM that contained a mixture of naphthalene (Naph.), phenanthrene (Phn.) and anthracene (Anth.) dissolved in ethylether to a final concentration of $1000 \mathrm{ppm}$ as a sole source of carbon, and the same steps were followed as listed before.

Isolates which showed growth and biodegradation potentials on Phn. were also inoculated separately into BSM that contained BX crude oil to a final concentration of $10 \%$ as a sole source of carbon and as an example of a real oil feed. The cultures were incubated at $30^{\circ} \mathrm{C}$ for one month, in a rotary shaking incubator (200rpm). The turbidity was monitored visually every five days. To determine degree of biodegradation; Cultures were acidified with $1 \mathrm{~N} \mathrm{HCl}$ to halt the microbial activity, and then crude oil was extracted with three volume of methylene chloride. The TPH concentration in the extract was determined gravimetrically [23]. The extracted oil samples were analyzed using GC/FID to determine the degree of biodegradation [24]. The percent loss of $n$ - and isoparaffins was calculated by comparing the peak areas obtained in the case of treated samples with those of crude oil used taking in consideration that the injected samples were exactly the same in all cases.

\section{RESULTS AND DISCUSSION}

\section{Hydrocarbon assessment of oil polluted soil samples}

The first step in assessing the state of petroleum hydrocarbons contamination in the oily soil (OS) samples involves determining the magnitude of its concentration. Quantitative determination of total petroleum hydrocarbons (TPH) for the studied samples is shown in Table (1).

The TPH values vary from 2107 up to $23983 \mu \mathrm{g} / \mathrm{g}$ soil dry weight (Table, 1). El-Tokhi and Moustafa, [23] classified the soil according to their TPH contamination levels as follows; 1 to $4 \mu \mathrm{g} / \mathrm{g}$ is unpolluted soil, $<100 \mu \mathrm{g} / \mathrm{g}$ is polluted soil but below the alarming level and up to $12,000 \mu \mathrm{g} / \mathrm{g}$ is highly polluted soil. According to Duarte et Al., [25], the levels of oil in low-polluted sites, averaged $710 \mu \mathrm{g} / \mathrm{g}$ of soil and those in the polluted sites, averaged $5,500 \mu \mathrm{g} / \mathrm{g}$ of soil. Based on these classifications, the obtained values were above the alarming level and can be considered to be highly polluted by oil.

The gas chromatographic pattern of the extracted oil from the studied OS samples is illustrated in Fig. (1). which reveals that the origin of contamination is mainly petrogenic. According to their chromatographic profile, the source of contamination of sediment samples is mainly weathered mixed fuel oils andlor used lubricating oil with weathered crude oil. Degree of weathering varies from one sample to the other, either weathered crude oil as in case of oily soil1 (OS1) or highly weathered crude oil in (OS2), or very highly weathered crude oil in (OS3). 


\section{Selection of biodegrading isolates}

Initially eight bacteria were isolated from the three collected soil samples.

Only two of them; ALN6 and ALN7 have showed an obvious growth and biodegradation potential of $99.9 \%$ and $99.97 \%$, respectively of $1000 \mathrm{ppm}$ Phn. as shown in Table (2). These two isolates were chosen for further studies.

\section{Identification of biodegrading isolates:}

ALN6 and ALN7 isolates were tentatively identified to be Pseudomonas aeruginosa sp. ANL6 and Brevibacterium casei sp. ALN7, respectively.

Brevibacterium strains were reported to degrade different PAHs [27-28].

Different Pseudomonas aeruginosa strains that attack aromatic and PAHs have also been isolated [29-33].

\section{Biodegradation Activities of isolated Microorganisms:}

It is obvious from the results listed in Tables (2 and3) that; bacterial isolates Pseudomonas aeruginosa ALN6 and Brevibacterium casei ALN7 prefer to utilize the three member ring as a sole $C$ and energy source than the diaromatic ring. Similar observation has been reported by MacLeod and Daugulis [13] and Mc Nally, et Al., [34].

Isolate Brevibacterium casei ALN7 showed nearly the same biodegradation level of Phn. in both sole-substrate and PAHs mixture systems $(99.97 \%$ and $98.10 \%$, respectively). However for isolate Pseudomonas aeruginosa ALN6 there was a great difference in biodegradation of $\mathrm{Phn}$. in sole-substrate system from that in $\mathrm{PAH}$ mixture-system $(99.90 \%$ and $35.38 \%$, respectively) which might indicate a competitive inhibition phenomenon (Guha et al., 1999). Kelly and Cerniglia [35] observed that the mineralization rates of individual PAHs were reduced by the presence of other PAH compound. Stringfellow and Aitken [36] reported competitive inhibition of phenanthrene uptake by naphthalene, methylnaphthalene and fluorene, due to the common enzyme systems responsible for biodegradation of a number of PAHs. Shuttleworth and Cerniglia [37] also observed inhibition of Phn. degradation in the presence of Naph., using three different microbial strains. Bouchez et Al., [16] also stated that naphthalene is a strongly toxic in a mixture of PAHs and can inhibit degradation of other components that would normally be biodegraded and this toxicity may be due to its high water solubility.

Data listed in Table (3) show differences in biodegradation rates observed for Phn. and Anth. although they have the same molecular weight which was more obvious with isolate Brevibacterium casei ALN7., this could be explained by differences in molecular structure features that govern reactivity and binding affinity for the enzymes responsible for biodegradation [38].

This study, and a few related studies, clearly shows that substrate interactions among a mixture of PAHs do not display simple degradation patterns despite similarities in chemical structure. Bouchez et Al., [16] have suggested that these same structural similarities, and the broad specificity of some enzymes, are what caused substrate interactions. This phenomenon presents obvious problems to those who rely on degradation rates of single compounds for modeling and remediation efforts. 
Based on the monitoring of turbidity change in the mineral medium supplemented with crude oil as a sole source of carbon, it can be observed that at the end of incubation period (4 weeks), in the control bottle, oil phase was located on top of the culture medium while in inoculated bottles the oil was emulsified with the aqueous phase. The increase in turbidity could be related to the microbial growth and oil emulsification in the water phase as a result of the effect of biosurfactants released during the microbial degrading activity. Similar observation was noticed by llyina et $\mathrm{Al}$, [39]. The \%loss in TPH was calculated, where Pseudomonas aeruginosa ALN6 and Brevibacterium casei ALN7 showed nearly the same biodegradation potential (95\% and $97 \%$, respectively) as illustrated in Table (4).

GC/FID analysis on control sample and inoculated crude oil revile that, There was a significant decrease in the resolvable peaks (normal (n)- and iso- paraffins) and the unresolvable complex mixtures (UCM), as listed in Table (4), and illustrated in Figure (2).

Generally, Pseudomonas aeruginosa ALN6 showed higher ability to degrade n- and iso- paraffins than that of Brevibacterium casei ALN7, while ALN7 showed higher ability to degrade UCM than ALN6. There is a general increase in the ratio of resolvable components/unresolvable components $\left(\mathrm{tC}_{\mathrm{n}} / \mathrm{UCM}\right)$; indicating the degradation of the UCM [40], which is in agreement with the results listed in Table (3), where ALN7 showed higher ability to degrade mixtures of PAHs than that of ALN6. According to Oudot [41], Gough and Rowland [42] and Pienkos [40]; the UCM contains PAHs and naphthenes. Several investigators used a number of parameters depending on gas chromatographic analysis which can be used as an indication of the relative state of biodegradation. The early effect of microbial degradation is monitored by the ratio of biodegradable to the less degradable compounds; Isoprenoid hydrocarbons are generally more resistant to biodegradation than normal alkanes. Thus, the ratio of normal alkane $\mathrm{nC}_{17}$ to its neighboring pristane $(\mathrm{Pr})$ $\left(\mathrm{nC}_{17} / \mathrm{Pr}\right)$, normal alkane $\mathrm{nC}_{18}$ to its neighboring phytane $(\mathrm{Ph})\left(\mathrm{nC}_{18} / \mathrm{Ph}\right), \mathrm{Pr} / \mathrm{Ph}$ and $\mathrm{n}-$ alkanes/iso-alkanes $\left(\mathrm{nC}_{n} /\right.$ iso $\left._{n}\right)$ are used as indices for the degree of biodegradation [43-44]. The obtained data in Table (4) show that, all treated samples have relatively higher $\mathrm{nC}_{17} / \mathrm{Pr}$ and $\mathrm{nC}_{18} / \mathrm{Ph}$ values compared with the control sample, indicating that these samples are highly biodegraded, and indicated also the degradation of $\mathrm{Pr}$ and $\mathrm{Ph}$, which is well recognized and illustrated in table (4) and Figure (2).

\section{CONCLUSION}

Brevibacterium casei ALN7 showed the same biodegradation efficiency on Phn. in both sole substrate and PAHs mixture (99.97\% and $98.10 \%$, respectively). However, Pseudomonas aeruginosa ALN6 showed a great difference on Phn. in sole substrate and PAHs systems $(99.90 \%$ and $35.38 \%$, respectively). They both showed high biodegradation ability on crude oil, $97 \%$ and $95 \%$ for Brevibacterium casei ALN7 and Pseudomonas aeruginosa ALN6, respectively. However, ALN6 was superior for degrading normal and iso- paraffins while ALN7 was superior for degrading unresolved complex mixture (UCM). 


\section{REFERENCES}

[1] Kirso, U.; Paalme, L.; Kullik, M. \& Irha, N., "Monitoring of carcinogenic hydrocarbons in the Baltic Sea", Baltic Sea Environmental Proceedings 19, pp. 479-487, (1986).

[2] Parhal, F. J. \& Crpenter, R., "Polycyclic aromatic hydrocarbons (PAH) - Phase associations in Washington coastal sediment, Geochim. Cosmochim. Acta, 47, pp. 48-62, (1983).

[3] Samanta, S.; Singh, O. V. \& Jain, R. K., "polycyclic aromatic hydrocarbon: environmental pollution and bioremediation", Trends Biotechnol., 20, pp. 243248, (2002).

[4] Kanaly, R. A. \& Harayama, S., "Biodegradation of high -molecular - weight polycyclic aromatic hydrocarbons by bacteria", J. Bacteriology, 182, pp. 20592067, (2000).

[5] Liu, k.; Han, W.; Pan, W. P. \& Riley, J. T., "Polycyclic aromatic hydrocarbon $(\mathrm{PAH})$ emissions from a coal fired pilot FBC system", J. Hazard. Mater., 84, pp.175-188, (2001).

[6] Moustafa, Y. M., "Contamination by polycyclic aromatic hydrocarbons in some Egyptian Mediterranean coasts", Bios. Biotechnol. Res. Asia 2(1), pp.15-24, (2004).

[7] Ke, L.; Teresa, W. Y.; Wong, Y. S. \& Nora, F. Y., "Fate of polycyclic aromatic hydrocarbon (PAH) contamination in a Mangrove swamp in Hong Kong folloing an oil spill”, Mar. Poll. Bull. 45(3-4), pp. 229-239, (2002).

[8] Mastrangelo, G., "Polycyclic aromatic hydrocarbons and cancer in man. Environ”, Health prospect, 104, pp.1166-1170, (1997).

[9] Goldman, R.; Enewold, L.; Pellizzori, E.; Beach, J. B; Bowman, E. D.; Krishnan, S. S. \& Shields P. G. "increase carcinogenic polycyclic aromatic hydrocarbons in human lung tissue Smoking", Cancer Res. 61(17), pp. 6367-6367, (2001).

[10] Bucker, M. Glatt, H R.; Platt, K. L. Avnir, D. Ittah, Y. Blum, J \& Oesch, F., "Mutagenicity of phenanthrene and phenanthrene K-region derivatives", Mutat. Res., 66, pp. 337-348, (1979).

[11] King, A J.; Readman, J W. \& Zhou, J H., "Dynamic behavior of polycyclic aromatic hydrocarbons in Brighton marine, UK", Mar. Poll. Bull., 48(3-4): pp.229-239, (2004).

[12] Guha, S.; Peters, C. A. \& Jaffe, P. R., "Multisubstrate biodegradation kinetics of naphthalene, phenantherene, and pyrene mixtures", Biotechnol. Bioeng., 65, pp. 491-799, (1999).

[13] Macleod, C. T. \& Dugulis, A. J., "Biodegradation of polyaromatic hydrocarbons in a two-phase portioning bioreactor in the presence of a bioavailable solvent", Appl. Micrbiol. Biotechnol., 62, pp. 291-296, (2003).

[14] Moody, J. D.; Freeman, J. P.; Doerge, D. R. \& Cerniglia C. E., "Degradation of phenanthrene and anthracene by cell suspensions of Mycobacterium sp. Strain PYR-1", Appl. Environ. Microbiol., 67(4), pp.1476-1483, (2001).

[15] Cerniglia, C. E., "Biodegradation of polycyclic aromatic hydrocarbon", Biodegradation, 3, pp. 351-368, (1992).

[16] Bouchez, M.; Blanchet, D. \& Vandecastelle J. P., "Degradation of polycyclic aromatic hydrocarbons by pure strains and by defined strain associations: Inhibition phenomena and cometabolism", Appl. Microbiol. Biotechnol., 43, pp.156-164, (1995). 
[17] Kirimura, K., Furuya, T., Nishii, Y., Yoshitaka, I., Kino, K. \& Usami, S. "Biodesulfurization of dibenzothiophene and its derivatives through the selective cleavage of carbon-sulfur bonds by a moderately thermophilic bacterium Bacillus subtlis WU-S2B", J. Biosci. Bioeng., 91(3), pp. 262-266 (2001).

[18] Constanti, M., Giralt, J. \& Bordons, A., "Degradation and desulfurization of dibenzothiophene sulfone and other sulfur compounds by Agrobacterium MC501 and a mixed culture", Enzyme \& Microbiol. Technol., 19, pp. 214-219, (1996).

[19] Readman, J. W., Fillmann, G., Tolosa, I., Bartocci, J., Villeneuve, I-P., Catinni, C. \& Mee, L. D., "Petroleum and PAH contamination of the Black Sea", Mari. Poll. Bull., 44, pp. 48-62, (2002).

[20] Zeng Eddy, Y., Kim, T. \& Diana Y., "Evaluation of potential molecular markers for Urban storm water runoff", Environmental Monitoring Assessment, 90 (1/3), pp. 23-43, (2004).

[21] Margesin, R., Labbé, D., Schinner, F., Greer, C. W. \& Whyte, L. G., "Characterization of hydrocarbon degrading microbial population in contaminated and pristine alpine soil”, Appl. Environ. Microbiol., 69(6): pp 30853092, (2003).

[22] Viguri, J., Verde, J. \& Irabien, A., "Environmental assessment of polycyclic aromatic hydrocarbons (PAHs) in surface sediments of the sanander Bay, Northern Spain". Chemosphere, 48, pp. 369-411 (2002).

[23] El-Tokhi, M .M. and Moustafa, Y. M., "Heavy Metals and petroleum hydrocarbons contamination of bottom sediment of EL-Sukhna area, Gulf of Suez, Egypt". Petroleum science and technology, 19(5, 6), pp. 481-494, (2001).

[24] Macnaughton, S. J., Stephen, J. R., Venosa, A. D., Davis, G. A., Chang, Y. \& White D. C., "Microbial population changes during bioremediation of an Experimental oil spill”, Appl. Environ. Microbiol., 65(8): pp. 3566-3574, (1999).

[25] Durate, G. F., Rosado, A. S., Seldin, L., Araujo, W. \& Van Elsas, J. D., "Analysis of bacterial community structure in sulfurous-oil-containing soils and detection of species carrying dibenzothiophene desulfurization $\left(d_{\mathrm{sz}}\right)$ genes", Appl. Environ. Microbiol., 67(3), pp.1052-1062, (2001).

[26] Abbad-Andaloussi, S., Warzywoda, M. \& Monot, F., "Microbial desulfurization of diesel oils by selected bacterial strains", Oil \& Gas Sci. Technol.-Rev. IFP, 58(4), pp. 505-513, (2003).

[27] Trenz, S P.; Engesser, K H.; Fischer, P.; Knackmuss, H J., "Degradation of fluorine by Brevibacterium sp. strain DPO 1361: a novel C-C bond cleavage mechanism via 1,10-dihydro-1,10-dihydroxyfluoren-9-one", J. Bacteriol., 45: pp.789-795, (1994).

[28] Chaillan, F.; Le Fleche, A.; Bury, E.; Phantavong, Y H.; Grimont P.; Saliot A.; Oudot J., "Biodegradation of mixtures of polycyclic aromatic hydrocarbons under aerobic and nitrate-reducing conditions", Res. in Microbiol., 55, pp. 587595, (2004).

[29] Ramirez, N., "Elucidation on sorption, desorption and biodegradation phenomena of pyrene spiked soils". M. S. thesis. The University of Akron, Akron, Ohio, (1999).

[30] Chayabutra, C. \& Ju L K., "Degradation of n-Hexadecane and Its metabolites by Pseudomonas aeruginosa under Microaerobic and Anaerobic Denitrifying Condition", Appl. Environ. Microbiol., 66, pp. 493-498, (2000). 
[31] Dean, S M; Jin, Y.; Cha, D K.; Wilson, S V. \& Radosevish, M., "Phenanthrene degradation in soils co-inoculated with Phenanthrene- degrading and biosurfactant- producing bacteria", J. Environ. Qual., 30, pp.1126-1133, (2001).

[32] Hwang S. \& Cutright T J., "Biodegradability of aged pyrene and phenanthrene in a natural soil", Chemosphere, 47, pp. 891-899, (2002).

[33] Jacques, R J S.; Santos, E C.; Bento, F M.; Peralba, M C R.; Selbach, P A.; Sa E L S. \& Camargo F A O., "Anthracene biodegradation by Pseudomonas sp. Isolated from a petrochemical sludge land farming site", Int. Biodeter. \& Biodeg., 56, pp143-150, (2005).

[34] McNally. D L.; Mihelcic, J R. \& Lueking D R., "Biodegradation of mixtures of polycyclic aromatic hydrocarbons under aerobic and nitrate - reducing conditions", Chemosphere, 38(6), pp. 1313-1321, (1999).

[35] Kelley, I. \& Cerniglia, C. E., "Degradation of a mixture of high-molecular-weight polycyclic aromatic hydrocarbons by a Mycobacterium strain PYR-1.", J. Soil Contam., 4, pp. 77-91, (1995).

[36] Stringfellow, W. T. \& Aitken, M. D., "Competitive metabolism of naphthalene, methylnaphthalenes, and fluorene by phenanthrene-degrading Pseudomonads", Appl. Environ. Micrbiol., 61, pp. 357-362, (1995).

[37] Shuttleworth, K. L. ; Cerniglia, C. E., "Bacterial degradation of low concentrations of phenanthrene and inhibition by naphthalene", Microbiol. Ecology. 31(3), pp. 305-317, (1996).

[38] Knightes, C D. \& Peters, C. A., "Statistical analysis of nonlinear parameter estimation for monod biodegradation kinetics using bivariate data", Biotechnol. \& Bioeng., 69, pp.160-170, (2000).

[39] Ilyina, A., Castillo Sanchez, M. I., Villarreal Sanchez, J. A., Ramirez Esquivel, G. \& Candelas, Ramirez, J., "Isolation of soil bacteria for bioremediation of hydrocarbon contamination", Bulletin of Moscow Uni. Series 2, Chem. 44(1), pp. 88-91, (2003).

[40] Pienkos, P T., "Choosing the best platform for the biotransformation of hydrophobic molecules" proceedings of the $8^{\text {th }}$ international symposium of microbiology ecology, Halifax, Nova Scotia, Canada, (August 9-14, 1998).

[41] Oudot, J., "Rates of microbial degradation of petroleum components as determined by computerized capillary gas chromatography and computerized mass-spectrometry", Mar. Environ. Res., 13, pp. 277-302, (1984).

[42] Gough, M A \& Rowland, S J., "Characterzation of unresolved complex mixtures of hydrocarbons in petroleum", Nature, 344, pp. 648-650, (1990).

[43] Sauer, T. C., Brown, J. S., Boehm, P. D., Aurand, D. V., Michel, J. \& Hayes M. O., "Hydrocarbon source identification and weathering characterization of intertidal and subtidal sediments along the Saudi Arabian coast after the Gulf War oil spill”, Mar. Pollut. Bull., 27, pp.117-134, (1993).

[44 Wang, Z. D., Fingas, M. \& Sergy, G., "Study of the effects of weathering on the chemical composition of a light crude oil using GC/MS GC/FID", Environ. Sci. Technol., 29, pp. 2622-2631, (1995). 
Table (1): Characterization of polluted samples

\begin{tabular}{|c|c|c|c|}
\hline Sample & DM\% & $\begin{array}{c}\text { Moisture } \\
\text { content \% }\end{array}$ & $\begin{array}{c}\text { TPH } \mu g / g \\
\text { (dry weight) }\end{array}$ \\
\hline OS1 & $97 \%$ & $3 \%$ & 23,983 \\
\hline OS2 & $74 \%$ & $26 \%$ & 2,107 \\
\hline OS3 & $96 \%$ & $4 \%$ & 6,647 \\
\hline
\end{tabular}

Table (2) Biodegradation of phenanthrene

\begin{tabular}{|c|c|c|c|c|}
\hline Source & Isolate & I// & pH & \%BD \\
\hline OS1 & ALN1 & ---- & 7.00 & ---- \\
\hline OS1 & ALN2 & --- & 7.00 & ---- \\
\hline OS1 & ALN3 & ---- & 7.00 & ---- \\
\hline OS1 & ALN4 & --- & 7.00 & --- \\
\hline OS1 & ALN5 & ---- & 7.00 & --- \\
\hline OS1 & ALN6 & 6.82 & 6.00 & $99.90 \%$ \\
\hline OS2 & ALN7 & 7.75 & 5.06 & $99.97 \%$ \\
\hline OS3 & ALN8 & --- & 7.00 & --- \\
\hline
\end{tabular}

Table (3) Biodegradation of mixture of $\mathrm{PAH}$

\begin{tabular}{|c|c|c|c|c|c|}
\hline Isolate & $\mathrm{I} / \mathrm{I}_{\mathrm{o}}$ & $\mathrm{pH}$ & \multicolumn{3}{|c|}{$\% B D$} \\
\hline \multirow{3}{*}{$\begin{array}{l}\text { Pseudomonas } \\
\text { aeruginosa } \\
\text { ALN6 }\end{array}$} & \multirow{3}{*}{5.60} & \multirow{3}{*}{6.15} & $\begin{array}{c}\text { Diaromatic } \\
\text { rings }\end{array}$ & Naph. & $18 \%$ \\
\hline & & & \multirow{2}{*}{$\begin{array}{l}\text { Three } \\
\text { aromatic } \\
\text { rings }\end{array}$} & Phn. & $35.38 \%$ \\
\hline & & & & Anth. & $36.74 \%$ \\
\hline \multirow{3}{*}{$\begin{array}{l}\text { Brevibacterium } \\
\text { casei } \\
\text { ALNL7 }\end{array}$} & \multirow{3}{*}{7.80} & \multirow{3}{*}{5.45} & $\begin{array}{c}\text { Diaromatic } \\
\text { rings }\end{array}$ & Naph & $9.45 \%$ \\
\hline & & & \multirow{2}{*}{$\begin{array}{l}\text { Three } \\
\text { aromatic } \\
\text { rings }\end{array}$} & Phn. & $98.10 \%$ \\
\hline & & & & Anth. & $81.03 \%$ \\
\hline
\end{tabular}

Table (4): Biodegradation of Belayim mix (BX) crude oil

\begin{tabular}{|l|c|c|c|}
\hline \multicolumn{1}{|c|}{ parameters } & Control & ALN6 & ALN7 \\
\hline $\mathrm{TPH}(\mathrm{g})$ & 3 & 0.16 & 0.09 \\
\hline \%loss of $\mathrm{TPH}$ & & 95 & 97 \\
\hline \% loss of $\mathrm{n}-$ and iso- $\mathrm{C}_{\mathrm{n}}$ & & 96 & 92 \\
\hline \% loss of $\mathrm{n}-\mathrm{C}_{\mathrm{n}}$ & & 97 & 93 \\
\hline \% loss of iso- $\mathrm{C}_{\mathrm{n}}$ & & 95 & 91 \\
\hline \% loss of $\mathrm{Pr}$ & & 99 & 92 \\
\hline \% loss of $\mathrm{Ph}$ & & 97 & 95 \\
\hline$\%$ loss of $\mathrm{UCM}$ & & 96 & 98 \\
\hline $\mathrm{Pr} / \mathrm{Ph}$ & 2.54 & 1.11 & 0.69 \\
\hline $\mathrm{nC} \mathrm{C}_{17} / \mathrm{Pr}$ & 1.72 & 4.98 & 2.20 \\
\hline $\mathrm{nC}_{18} / \mathrm{Ph}$ & 0.28 & 7.51 & 1.50 \\
\hline $\mathrm{nC}_{\mathrm{n}} / \mathrm{isoC}_{\mathrm{n}}$ & 1.72 & 0.97 & 1.36 \\
\hline $\mathrm{tC}_{\mathrm{n}} / \mathrm{UCM}$ & 0.28 & 0.84 & 1.99 \\
\hline
\end{tabular}




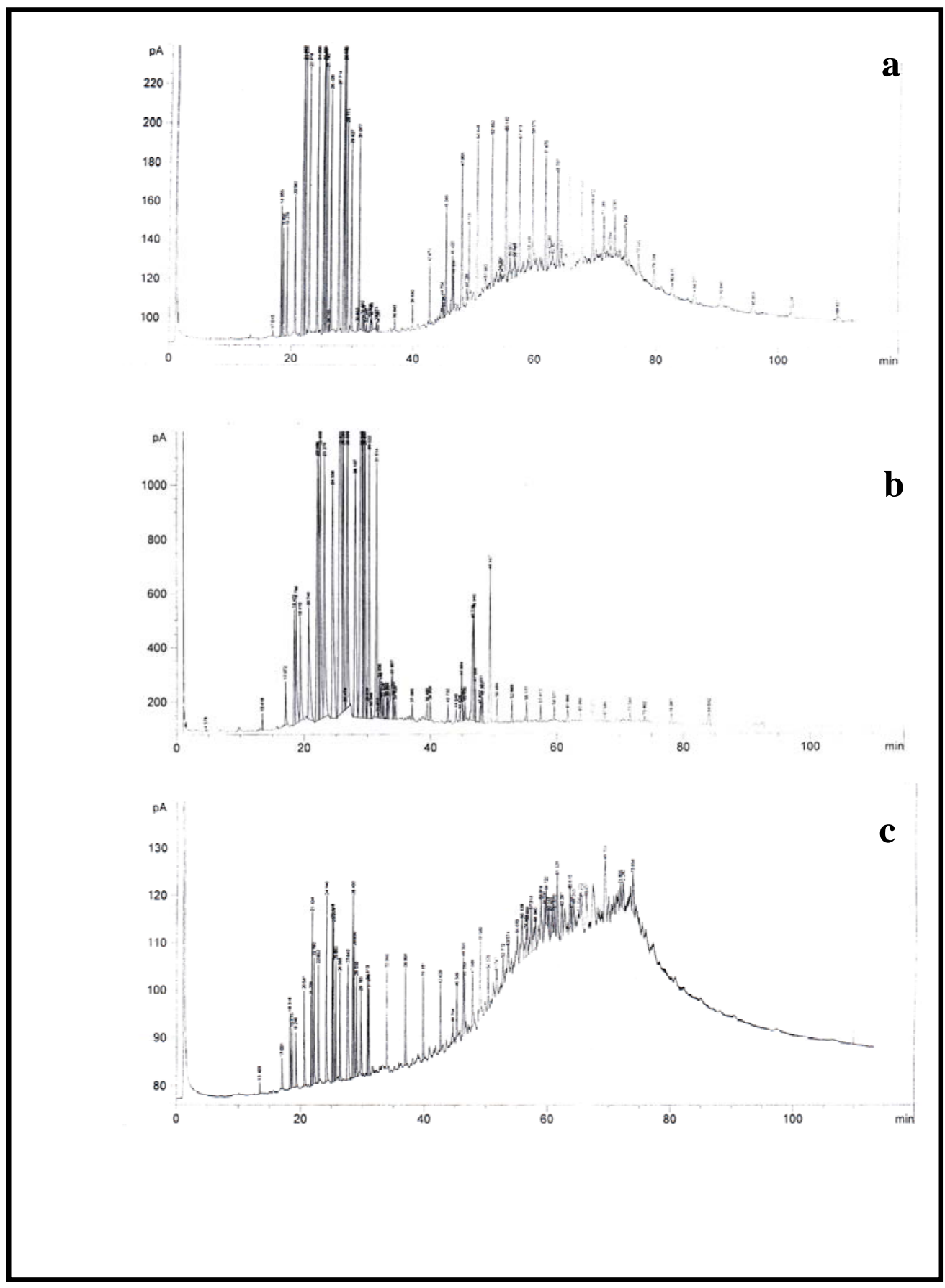

Fig. (1): Gas chromatographic profile of extracted oil from the studied samples
(a) OS1
(b) OS2
(c) OS3 


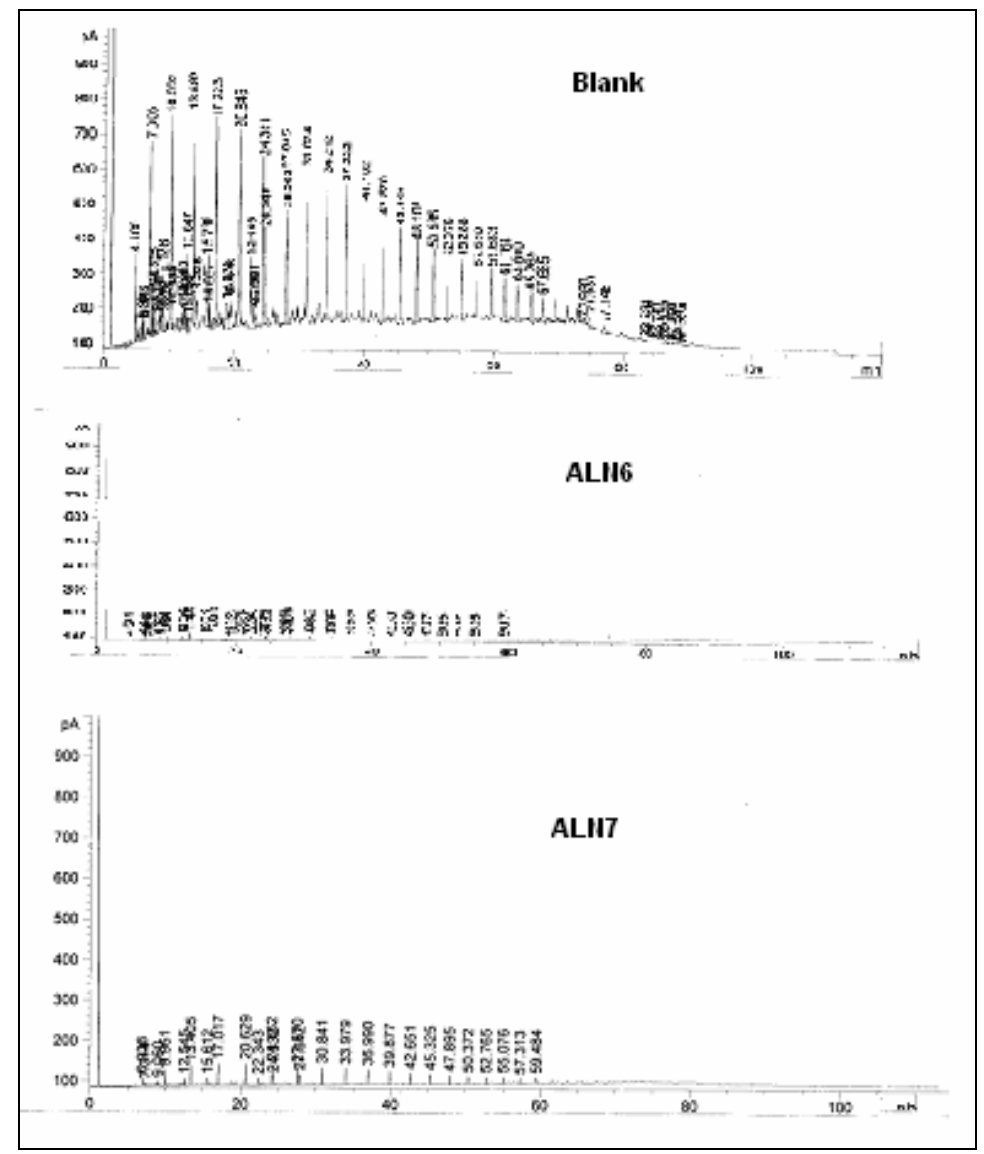

Fig (2): GC Chromatogram represents the bacterial degradation of crude oil 